\title{
Endovascular correction of venogenic erectile dysfunction in May-Thurner syndrome (clinical case)
}

\author{
E.A. Povelitsa ${ }^{1}$, A.V. Bystrenkov ${ }^{2}$, A.M. Shesternya ${ }^{1}$, O.V. Parkhomenko ${ }^{1}$ \\ ${ }^{1}$ Republican Research Center for Radiation Medicine and Human Ecology; 290 Ilyicha St., Gomel 246000, Republic of Belarus; \\ ${ }^{2}$ Gomel Regional Clinical Hospital; 5 Bratyev Lizyukovykh St., Gomel 246000, Republic of Belarus \\ Contact: Eduard Anatolievich Povelitsa povelitsaed@gmail.com
}

Introduction. Secondary varicose small pelvic veins with the development of chronic venous insufficiency due to obstruction of the magistral venous vessels, in particular, the left common iliac vein and the right common iliac artery (May-Thurner syndrome), occupy a special place in the structure of the causes of venogenic erectile dysfunction (ED).

The study objective is to present the clinical case of arteriovenous conflict (May-Thurner syndrome), leading to the development of secondary varicose small pelvic veins in men and venogenic ED, as well as modern methods of its verification and endovascular surgical repair.

Clinical case. A clinical case of successful endovascular correction of venogenic ED is presented. The patient is diagnosed with: MayThurner syndrome. Pelvic varicose disease C3 (according to CEAP Classification). Condition after endovascular balloon angioplasty and stenting of the left common iliac vein. Bilateral varicocele. Condition after bilateral varicocelectomy in 2018. Severe venogenic ED (pathological venous drainage, proximal type, International Index of Erectile Function (v. 5) - 12 points; Er3 according to the Unem Scale) in accordance with the Comprehensive Classification System for Chronic Venous Disorders. On July 24, 2019 endovascular occlusion of the Santorini's plexus veins was performed with the installation of occlusion spirals in their lumen according to Gianturco. In order to provide visualization of the veins in the Santorini's plexus, given the impossibility of cannulation of the deep vein of the penis, bilateral symmetrical cannulation of the cavernous bodies of the penis was carried out to perform cavernosophlebography. The left common iliac vein was catheterized according to the Crossover technique. Under phlebography control we ensured that the stent in the common iliac vein passed without signs of loss of its lumen. The internal pudental vein on the left was selectively catheterized. Hydrophilic guidewire was introduced through the veins of the periprostatic plexus into the right internal pudental vein. Selective catheterization of the periprostatic venous plexus was not possible due to pronounced tortuosity, valve flaps of the veins and small diameter of the catheterized veins. It was decided to pass the guidewire further through the right iliac vein system with access to the inferior vena cava. Further, the guidewire was again transferred to the left common iliac vein (double crossover). The left common femoral vein was punctured followed by the placement of 5 Fr introducer sheath according to Seldinger. The guidewire tip was fixed by the loop in the left common iliac vein, then captured and brought out through the introducer in the left common femoral vein. A catheter Cobra $15 \mathrm{Fr}$ was inserted through a crossover guide from the left common femoral vein into the right internal iliac vein and further into the periostatic venous plexus. Gradually veins of the Santorini's plexus were selectively catheterized followed by Gianturco coils embolization.

Conclusion. The first choice surgery for verified proximal type ED is endovascular occlusion of the veins in the Santorini's plexus through the deep vein of the penis, which allows to change the hemodynamics in the penis and provide sufficient erection without resorting to endofalloprosthesis of the penis. Single or double-sided transfemoral access is suggested for patients when access through the deep vein of the penis is rather challenging or absent.

Key words: May-Thurner syndrome, endovascular occlusion, venogenic erectile dysfunction

For citation: Povelitsa E.A., Bystrenkov A.V., Shesternya A.M., Parkhomenko O.V. Endovascular correction of venogenic erectile dysfunction in May-Thurner syndrome (clinical case). Andrologiya i genital'naya khirurgiya = Andrology and Genital Surgery 2019;20(4):45-51.

DOI: $10.17650 / 2070-9781-2019-20-4-45-51$

\section{Эндоваскулярная коррекция веногенной эректильной дисфункции при синдроме Мея-Тернера (клиническое наблюдение)}

\section{Э.А. Повелица ${ }^{1}$, А.В. Быстренков ${ }^{2}$, А.М. Нестерня ${ }^{1}$, О.В. Пархоменко}

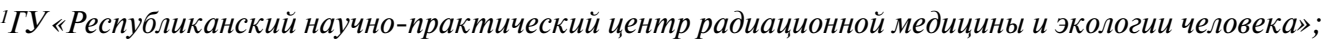
Республика Беларусь, 246000 Гомель, ул. Ильича, 290;

${ }^{2}$ Гомельская областная клиническая больница; Республика Беларусь, 246000 Гомель, ул. Братьев Лизюковых, 5

Введение. Особое место в структуре причин веногенной эректильной дисфункции (ЭД) занимает вторичное варикозное расширение вен малого таза с развитием хронической венозной недостаточности вследствие обструкции магистральных венозных сосудов, в частности общей левой подвздошной вены правой общей подвздошной артерией, что называется синдромом МеяТернера. 
Цель сообщения - представить клинический случай артериовенозного конфликта, приводящего к развитию вторичного варикозного расширения вен малого таза у мужчин и веногенной ЭД, а также описать современные методы его верификации и эндоваскулярного хирургического лечения.

Клиническое наблюдение. Описан клинический случай успешной эндоваскулярной коррекции веногенной ЭД у пациента с диагнозом: синдром Мея-Тернера, варикозная болезнь малого таза С3 (по Международной классификации хронических заболеваний вен CEAP(Comprehensive Classification System for Chronic Venous Disorders)), состояние после эндоваскулярной баллонной ангиопластики и стентирования левой общей подвздошной вены, двустороннее варикоцеле, состояние после двусторонней варикоцелэктомии (2018 г.), веногенная ЭД тяжелой степени (патологический венозный дренаж, проксимальный тип, международный индекс эректильной функции - 12 баллов; Еr3 по шкале Юнема) в соответствии с Международной классификацией хронических заболеваний вен. 24 июля 2019 г. выполнена эндоваскулярная окклюзия вен сплетения Санторини с установкой в их просвет окклюдирующих спиралей Gianturсо. С иелью обеспечения визуализации вен сплетения Санторини, учитывая невозможность канюляции глубокой вены полового члена, осуществили двустороннюю симметричную канюляцию кавернозных тел полового члена для выполнения кавернозофлебографии. По методике crossover введен катетер в левую общую подвздошную вену. При флебографии подтверждена проходимость стента в общей подвздошной вене, отсутствие признаков сужения просвета. Селективно катетеризирована внутренняя половая вена слева. Через вены перипростатического сплетения в правую внутреннюю половую вену проведен гидрофильный проводник. Селективно катетеризировать перипростатическое венозное сплетение не удалось ввиду выраженной извитости. наличия створок клапанов вен и малого диаметра катетеризированных вен. Принято решение провести проводник далее по правой подвздошной вене с выходом в нижнюю полую вену. Далее проводник был вновь переведен в левую общую подвздошную вену (double crossover). Пунктирована левая общая бедренная вена по Сельдингеру с установкой интродьюсера диаметром 5 Fr. Петлей для захвата проводника в левой общей подвздошной вене фиксирован кончик проводника, захвачен и выведен наружу через интродьюсер в левой общей бедренной вене. По проводнику из левой общей бедренной вены в правую внутреннюю подвздошную вену и далее в перипростатическое венозное сплетение проведен катетер Cоbra 1 диаметром 5 Fr. Cелективно поэтапно катетеризированы основные пути венозной утечки и эмболизированы металлическими спиралями Giаntигсо. Заключение. Операцией выбора после верификации веногенной ЭД проксимального типа считается эндоваскулярная окклюзия вен сплетения Санторини через глубокую вену полового члена, которая позволяет изменить гемодинамику в половом члене и обеспечить достаточную эрекцию, не прибегая к эндофаллопротезированию. При возникновении технических трудностей - при отсутствии точки доступа через глубокую вену полового члена - применяют одно- или двусторонний трансфеморальный доступ.

Ключевые слова: синдром Мея-Тернера, эндоваскулярная окклюзия, веногенная эректильная дисфункция

Для цитирования: Повелица Э.А., Быстренков А.В., Шестерня А.М., Пархоменко О.В. Эндоваскулярная коррекция веногенной эректильной дисфункции при синдроме Мея-Тернера (клиническое наблюдение). Андрология и генитальная хирургия 2019;20(4): 45-51. (На англ.).

\section{Introduction}

Venogenic erectile dysfunction (ED) can be also associated with pelvic varicose disease. Secondary varicose small pelvic veins with the development of chronic venous insufficiency due to compression of the main venous vessels, in particular, the left common iliac vein by the right common iliac artery, occupy a special place in the structure of the causes of venogenic ED. This proximal arteriovenous conflict is recognized in the literature as May-Thurner syndrome (MTS). Compression of the left common iliac vein can cause the impaired venous outflow from the left lower extermity and pelvic organs, which leads to venous congestion and subsequent development of varicose small pelvic veins [1-5].

MTS is the leading cause for the development in men of varicocele, venogenic $E D$, varicose veins of the saphenous veins of the penis and left lower extermity, chronic pelvic and scrotal pain and chronic congestive prostatitis $[1,6]$.

Such a wide variety of clinical manifestations of MTS can be explained by close relation between the superficial and deep venous systems of the androgenital zone through the communicant veins (scrotal veins, spermatic cord, penis, veins of the internal iliac venous system and the safeno- femoral junction). Reported prevalence of MTS ranges from 2.7 to $32.0 \%$ [7-9].

Currently, the main effective approach to treatment for MTS is endovascular balloon angioplasty of the left common iliac vein with stent placement in its lumen in the compression area by the right common iliac artery [1, 3-6].

In the postoperative period in a patient with MTS, after surgical repair of the arteriovenous conflict and the left common iliac vein compression, we observe the improvement of venous outflow from the pelvic organs, and at the same time, the aggravation of venogenic ED symptoms. It occurs due to the previously developed varicose veins in the Santorini's plexus and valve insufficiency of these veins. As a result, it leads to the development of a pronounced venous reflux from the penis, so-called proximal venous leak disease, and in some cases distal venous leak disease, due to the developed multiple venous anastomoses through $v v$. obturatoria with $v v$. pudenda externa in the safenofemoral junctions [7].

According to the European Association of Urology [10] and American Urological Association [11] the current first choice treatment option for venogenic ED is applying phosphodiesterase type 5 (PDE5) inhibitors and endofalloprosthesis. 
However, modern topographic and anatomical insight about the venous system of the penis and pelvic varicose disease in men allow one to consider alternative methods of surgical repair of venogenic ED, in particular, endovascular occlusion of veins in the Santorini's plexus as one of the stages of the change in penile hemodynamics. And in the case of pelvic varicose disease progression after endovascular intervention (occlusion of veins in the Santorini's plexus) combined with distal-type venous leak of penis, it is possible to perform combined phlebectomy of $v v$. pudendae externae in the area of saphenofemoral junctions on both sides with obligatory simultaneous circumcision surgery and ligation of the communicant vein in the area of the sulcus coronarius of the penis in order to maximize the separation of the superficial and deep venous systems of the penis [7, 9, $12,13]$.

In this regard, the surgical repair of venogenic ED by performing endovascular occlusion of the veins in the Santorini's plexus in order to eliminate venous reflux through the deep vein of penis is of some practical interest [12].

The study objective is to present the clinical case of arteriovenous conflict (MTS), leading to the development of secondary varicose small pelvic veins in men and venogenic ED, as well as modern methods of its verification and endovascular surgical repair.

\section{Clinical case}

In July 2019, we consulted 30-year-old patient Z. with complaints of ED over the past few years, which worsened significantly after endovascular surgery - placement of stent to the left common iliac vein for MTS. From the anamnesis and on the basis of the medical documents provided, digital media with records of previous surgical and diagnostic interventions, the following was determined.

For an extended period of time, the patient suffered from constant pain in the lumbosacral spine, radiating to the pelvis, constant aching pain in the perineum, scrotum, aggravated during physical activity. In connection with these complaints, the patient repeatedly consulted neurologist, urologist. Based on the results of the examination, the patient was diagnosed with osteochondrosis of the lumbosacral spine, lumbago, and chronic prostatitis. However, the treatment was ineffective as the patient reported about above-mentioned complaints.

Over time, on the background of these complaints, the patient noted a deterioration of erectile function. An erection arose as usual on stimulation, but then it disappeared soon at vaginal penetration.

In this regard, in March 2018, the patient consulted a specialized clinic in Moscow (Russia), where MTS and chronic syndrome of pelvic venous plethora were detected in the result of a comprehensive examination, which included ultrasound duplex scanning of the iliac veins, pelvic veins, scrotum, and penile vessels. The patient was verified with bilateral varicocele, venous dilatation of the prostatic plexus during transrectal ultrasound examination, as well as a significant narrowing of the left common iliac vein due to its compression by the right common iliac artery (fig. 1).

The patient was offered, and then performed, endovascular balloon angioplasty of the left common iliac vein with subsequent installation of a nitinol stent in its lumen for MTS (fig. 2, 3).

After some time, the patient underwent bilateral varicocelectomy for varicose veins of the spermatic cord on both sides. In the postoperative period, the patient noted a significant improvement: the pain in the scrotum, pelvis and perineum practically disappeared, however, the patient did not notice an improvement in erectile function after the surgeries performed.

After 6 months, the patient's erection started to deteriorate progressively and there was noted an increase of ED according to the International Index of Erectile Function (IIEF-5) up to $12-14$ points.

Due to the suspicion of venogenic ED, the patient underwent dynamic pharmacocavernous phlebography in June 2019 in Moscow (Russia). Based on the analysis of the obtained images, a significant venous reflux into the veins of the Santorini's plexus was detected in patient. Varicose veins of the small pelvis were 5-6 $\mathrm{mm}$.

At dopplerography of the vessels of penis, the blood flow velocity through the deep vein of the penis was more than $20 \mathrm{~cm} / \mathrm{s}$ (normal $5-10 \mathrm{~cm} / \mathrm{s}$, there were no changes in blood flow in the arteries of the penis and the peak systolic blood flow velocity was normal).

Dopplerography also revealed that the deep vein of the penis in the root area was not of the magistral, but of the finely branched type of structure, which greatly complicated the implementation of the planned endovascular occlusion of the veins

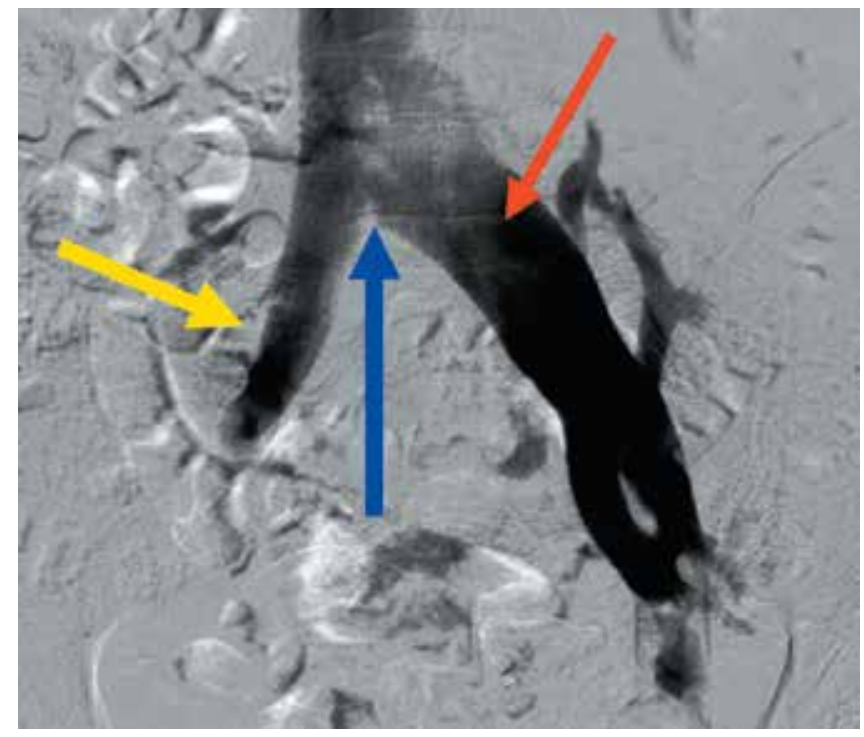

Fig. 1. Phlebogram of varicose dilated left common iliac vein (red arrow), bifurcation of the inferior vena cava (blue arrow), unchanged right common iliac vein (yellow arrow) in a patient with May-Thurner syndrome. The ratio of the diameters of the right and left common iliac veins 1:2 (photograph by A.A. Kapto, 2018)

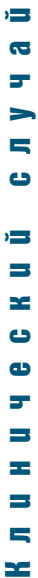




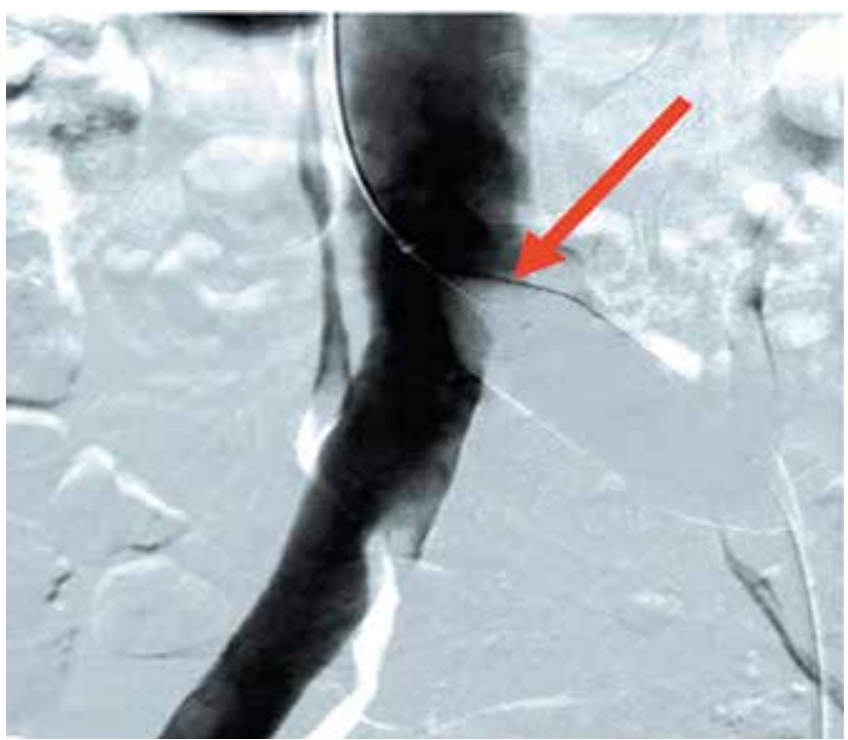

Fig. 2. Phlebogram, stage of interventional balloon angioplasty of the left common iliac vein (red arrow) in a patient with May-Thurner syndrome (phtotograph by A.A. Kapto, 2018)

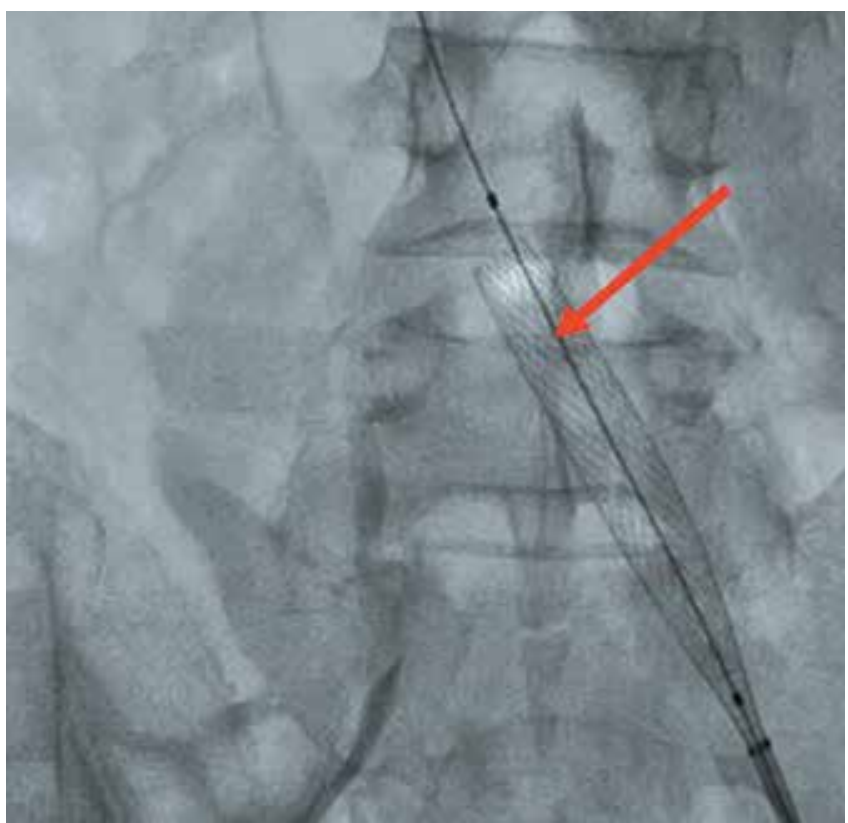

Fig. 3. Phlebogram, stage of interventional stenting of the left common iliac vein (red arrow) in a patient with May-Thurner syndrome (phtotograph by A.A. Kapto, 2018)

in Santorini's plexus at access (access point) through the deep vein of the penis.

Subsequently, an attempt to isolate the deep vein of the penis was unsuccessful due to its branched structure type and, as a result, endovascular occlusion of varicose veins in the Santorini's plexus was not possible.

In July 2019, the patient consulted in the Republican Research Center for Radiation Medicine and Human Ecology, Gomel (Republic of Belarus), where, based on review of the provided medical records, complaints (the IIEF-5 ED was 10-12 points), and also taking into account the patient's unwillingness to perform endofalloprosthesis and the inefficiency of PDE5 inhibitors, the patient was diagnosed with: MTS. Pelvic varicose disease C3 (according to CEAP Classification, 10). Condition after endovascular balloon angioplasty and stenting of the left common iliac vein. Bilateral varicocele. Condition after bilateral varicocelectomy in 2018. Severe venogenic ED (pathological venous drainage, proximal type, IIEF-5 - 12 points; Er3 according to the Unem scale) in accordance with the Comprehensive Classification System for Chronic Venous Disorders [14].

Taking into account the lack of access through the deep vein of the penis, the patient was offered an intervention by right-sided transfemoral access to install occlusion spirals in the veins in the Santorini's plexus and, thus, eliminate proximal venous leak. The surgery was performed on the basis of the Gomel Regional Clinical Hospital (Republic of Belarus).

$X$-ray endovascular examination and surgery were performed on Philips Allura Xper FD20 two-projection angiography system.

Erectile dysfunction was assessed according to the IIEF-5 before and after the surgery.

On July 24, 2019 in X-ray endovascular operating room under local anesthesia endovascular occlusion of the Santorini's plexus veins was performed with the installation of occlusionspirals in their lumen according to Gianturco.

In order to provide visualization of the veins in the Santorini's plexus, given the impossibility of cannulation of the deep vein of the penis, bilateral symmetrical cannulation of the cavernous bodies of the penis was carried out to perform cavernosophlebography with the permanent administration of an X-ray contrast substance "Tomohexol 350" (Farmak, Ukraine) at a dilution of $1: 3$ with $0.9 \% \mathrm{NaCl}$ solution (fig. 4).

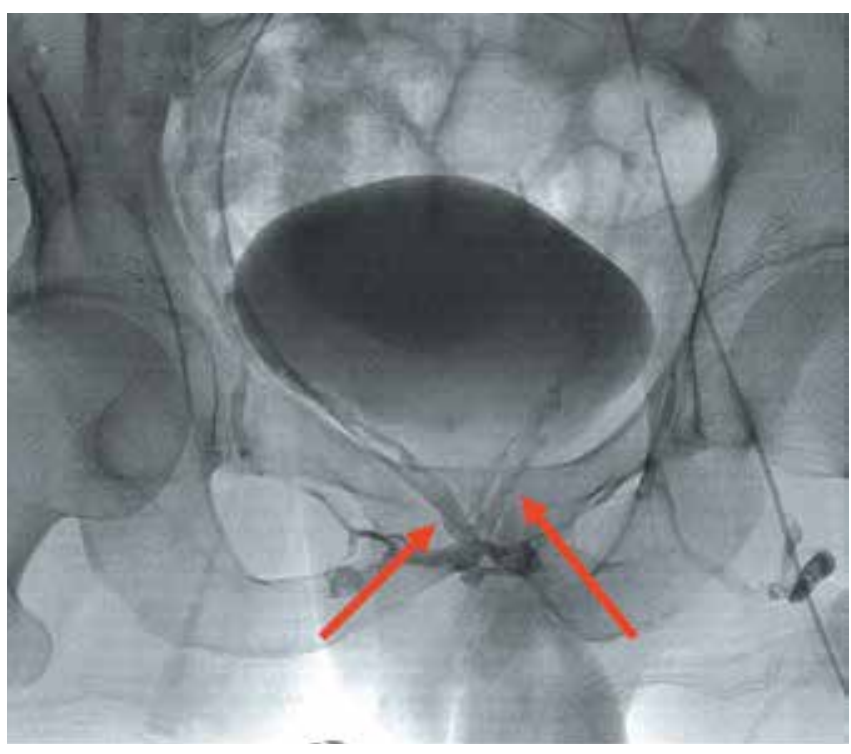

Fig. 4. Phlebogram, stage of visualization of the Santorini's plexus (red arrows) by performing cavernosography in a patient with May-Thurner syndrome and venogenic erectile dysfunction (photograph by E.A. Povelitsa, 2019) 
Operative report dated 07/24/2019. The start time of the surgery is 15.00; the end time of the surgery is 17.45. The right common femoral vein was punctured followed by the placement of $5 \mathrm{Fr}$ introducer sheath according to Seldinger. The left common iliac vein was catheterized according to the crossover technique. Under phlebography control we ensured that the stent in the common iliac vein passed without signs of loss of its lumen. The internal pudental vein on the left was selectively catheterized. Hydrophilic guidewire ("Radifocus", Terumo, Belgium) was introduced through the veins of the periprostatic plexus into the right internal pudental vein. Localization control of the guidewire was carried out using cavernosography. Selective catheterization of the periprostatic venous plexus was not possible due to pronounced tortuosity, valve flaps of the veins and small diameter of the catheterized veins. It was decided to pass the guidewire further through the right iliac vein system with access to the inferior vena cava. Further, the guidewire was again transferred to the left common iliac vein (double crossover). The left common femoral vein was punctured followed by the placement of 5 Fr introducer sheath according to Seldinger. The guidewire tip was fixed by the loop (Cook Medical, Denmark) in the left common iliac vein, then captured and brought out through the introducer in the left common femoral vein. A catheter Cobra1 5 Fr (Balton, Poland) was inserted through a crossover guide from the left common femoral vein into the right internal iliac vein and further into the periostatic venous plexus. Gradually veins of the Santorini's plexus were selectively catheterized followed by Gianturco coils embolization (fig. 5-7).

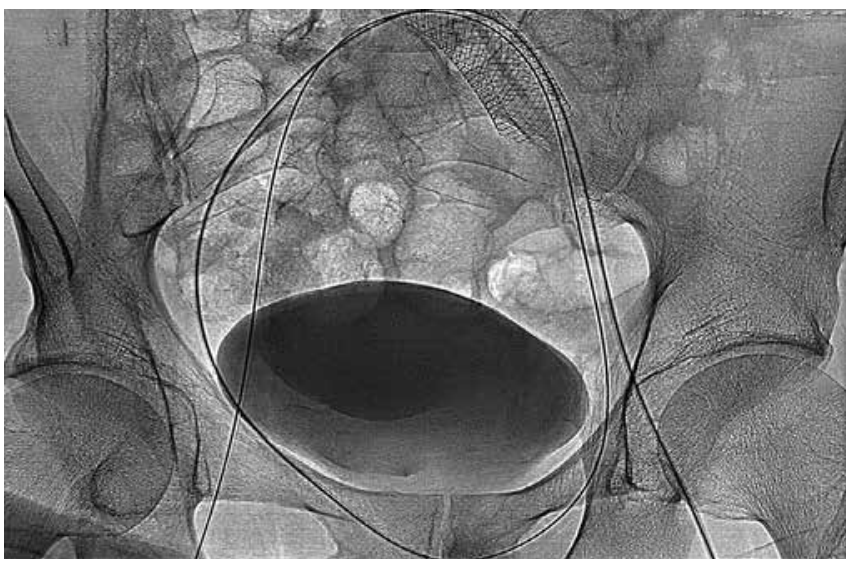

Fig. 5. Phlebogram, stage of introduction of the guidewire through transfemoral access on the right along the "route" - the femoral vein on the right, the external and common iliac vein on the right, the bifurcation of the inferior vena cava, the common (with the stent installed) and the internal iliac vein on the left, the Santorini's plexus, the internal iliac vein on the right, common iliac vein on the right, bifurcation of the inferior vena cava, common (with a stent installed) and external iliac vein on the left with subsequent capture of the guide loop and leading it out through the left transfemoral access for subsequent retrograde endovascular catheter insertion and introduction of occlusion spirals into the Santorini's venous plexus under the finely branched nature of the structure of the deep vein of the penis in a patient with May-Thurner syndrome and venous erectile dysfunction due to the development of proximal venous leak after elimination of venous obstruction by stenting of common iliac vein on the left in 2018 (photogragh by E.A. Povelitsa, 2019)

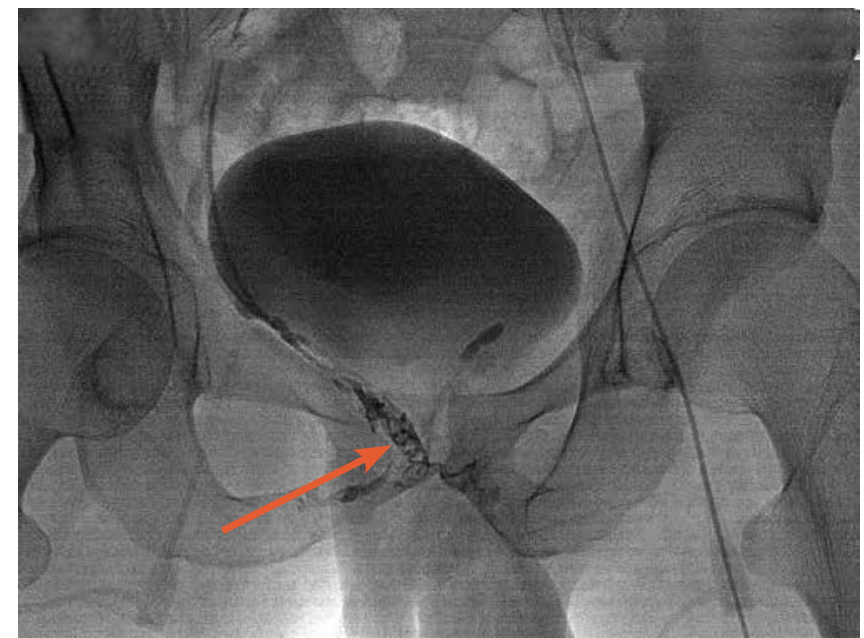

Fig. 6. Phlebogram, stage of introduction of occlusion spirals (red arrow) in the Santorini's plexus in a patient with May-Thurner syndrome and venogenic erectile dysfunction (photograph by E.A. Povelitsa, 2019)

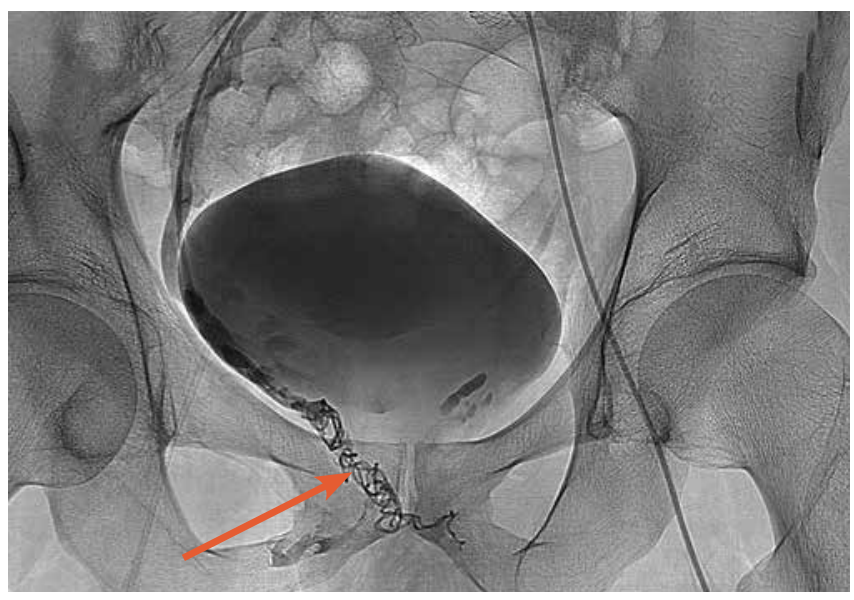

Fig. 7. Phlebogram, final stage of introduction of 8 occlusion spirals (red arrow) in the Santorini's plexus in a patient with May-Thurner syndrome and venogenic erectile dysfunction (photograph by E.A. Povelitsa, 2019)

The patient was discharged from the hospital in satisfactory condition the next day after surgery without complications. After 7 days, the patient experienced spontaneous nocturnal penile tumescence, of sufficient tension and of sufficient duration in time, which disappear independently. One month after the endovascular blocking of the veins in the Santorini's plexus, the patient proceeded to a full sexual life satisfied by surgery outcome without applying PDE5 inhibitors.

\section{Conclusion}

In a patient with MTS, after surgical repair of the arteriovenous conflict with endovascular balloon angioplasty and stenting of the left common iliac vein in the postoperative period, a marked deterioration in erectile function occurs during the first year, due to the previously developed varicose veins in the Santorini's plexus and valve insufficiency of the veins, which contributes to the development 
of venous leak from penis of both proximal and distal types, and due to multiple venous anastomoses between the pelvic vein system and saphenofemoral junctions [1,8].

The first choice surgery for verified proximal type ED is Kurbatov's operation - endovascular occlusion of the veins in the Santorini's plexus through the deep vein of the penis, which allows to change the hemodynamics in the penis and provide sufficient erection without resorting to endofalloprosthesis of the penis [12].

In the event when it is impossible to catheterize the deep vein of the penis due to its finely branched type of structure and associated technical difficulties in visualizing the pelvic veins for performing an intervention, permanent cavernosography by symmetric cannulation of two cavernous bodies of the penis can be considered as appropriate topographic imagining technique at installing occlusion spirals.
Single or double-sided transfemoral access is suggested for patients when access through the deep vein of the penis is rather challenging or absent.

The installation of occlusion spirals can be performed successfully both orthogradely and retrogradely through contralateral transfemoral access under certain conditions and provided technical equipment.

Previously installed stent in the left common iliac vein does not affect the technical implementation of the endovascular occlusion of veins in the Santorini's plexus.

The presented clinical case demonstrates the possibility of a stepwise approach in correcting the manifestations of pelvic varicose veins in men due to arteriovenous fistula (MTS), as well as the wide possibilities of endovascular surgery for venogenic ED without resorting to penile endofalloprosthesis.

\section{R E}

1. Жуков О.Б., Уколов В.А., Сниткин В.М. и др. Синдром МэяТернера у мужчин. Андрология и генитальная хирургия 2017;18(1):39-47. [Zhukov O.B., Ukolov V.A., Snitkin V.M. et al. May-Thurner syndrome in men. Andrologiya i genital'naya khirurgiya = Andrology and Genital Surgery 2017;18(1):39-47. (In Russ.)]. DOI: 10.17650/2070-9781-2017-18-139-47.

2. Жуков О.Б., Капто А.А., Михайленко Д.С., Евдокимов В.В. Варикозная болезнь органов таза мужчины. Андрология и генитальная хирургия 2016;17(4):72-7. [Zhukov O.B., Kapto A.A., Mikhaylenko D.S., Evdokimov V.V. Varicose veins of the pelvis men. Andrologiya i genital'naya khirurgiya = Andrology and Genital Surgery 2016;17(4):72-7. (In Russ.)]. DOI: 10.17650/2070-9781-2016-174-72-77.

3. Chamarthy M.R., Sutphin P., Anderson M. et al. Evolving concepts in the diagnosis and management of May-Thurner syndrome. J Clin Interv Radiol 2017;1:23-30. DOI: $10.1055 / \mathrm{s}-0036-1597954$.

4. Жуков О.Б., Зубарев А.Р., Кульченко Н.Г. Патологический венозный дренаж кавернозных тел полового члена у больных с варикоцеле. Медицинская визуализация 2006;1:82-9. [Zhukov O.B., Zubarev A.R., Kulchenko N.G. Pathological venous drainage of cavernous bodies in patients with varicocele. Meditsinskaya vizualizatsiya $=$ Medical Visualization 2006;1:82-9. (In Russ.)].

5. Bozkaya H., Cinar C., Ertugay S. et al. Endovascular treatment of iliac vein compression (May-Thurner) syndrome: angioplasty and stenting with or without manual aspiration thrombectomy and catheter-directed thrombolysis. Ann Vasc Dis 2015;8(1):21-8.

DOI: $10.3400 /$ avd.oa.14-00110.

6. Goldman R.E., Arendt V.A., Kothary N. et al. Endovascular management of May-Thurner syndrome in adolescents: a single-center experience. J Vasc Interv Radiol 2017;28(1):71-7. DOI: 10.1016/j.jvir.2016.09.005.

7. Страхов С.Н. Варикозное расширение вен гроздевидного сплетения и семенного канатика (варикоцеле). М.: Астра-семь, 2001. 235 с. [Strakhov S.N. Varicose veins of the groin-like plexus and spermatic cord (varicocele). Moscow: Astra-sem, 2001. 235 p. (In Russ.)].

8. Повелица Э.А., Аничкин В.В. Естественные предпосылки возникновения органической эректильной дисфункции. Медико-биологические проблемы жизнедеятельности 2016;(1):186-94. [Povelitsa E.A., Anichkin V.V. Natural preconditions for development of organic erectile dysfunction. Medikobiologicheskie problemy zhiznedeyatelnosti $=$ Medical and Biological Problems of Life Activity 2016;(1):186-94. (In Russ.)].

9. Цуканов А.Ю., Ляшев Р.В. Варикозная болезнь малого таза как причина патоспермии и пути ее коррекции. Андрология и генитальная хирургия
2014;15(2):74-80. [Tsukanov A.Yu. Lyashev R.V. Small pelvic varices as a cause of pathospermia and ways of its correction. Andrologiya i genital'naya khirurgiya $=$ Andrology and Genital Surgery 2014;15(2):74-80. (In Russ.)]. DOI: 10.17650/2070-9781-2014-2-74-80.

10. European Association of Urology. Male sexual dysfunction. Available at: http:// uroweb.org/guideline/male-sexualdysfunction/\#3.

11. Erectile dysfunction: AUA Guideline (2018). Available at: https://www.auanet. org/guidelines/erectile-dysfunction-(ed)guideline.

12. Диагностика и лечение веногенной эректильной дисфункции. Под ред. Д.Г. Курбатова. М.: Медпрактика-М, 2017. 256 c. [Diagnostics and treatment of venogenic erectile dysfunction. Ed. by D.G. Kurbatov. Moscow: Medpraktika-M, 2017. 256 p. (In Russ.)].

13. Повелица Э.А., Доста Н.И., Шестерня А.М. и др. Комбинированная флебэктомия при андрогенитальной форме варикозной болезни вен малого таза. Андрология и генитальная хирургия 2019;20(1):61-8. [Povelitsa E.A., Dosta N.I., Shesternya A.M. et al. Combined phlebectomy in androgenital form of varicosity veins of small pelvis. Andrologiya i genital'naya khirurgiya = Andrology and Genital Surgery 2019; 20(1):61-8. (In Russ.)]. DOI: 10.17650/ 2070-9781-2019-20-1-61-68.

14. International Classification of Chronic Lower Vein Disease (CEAP) - prospects for implementation. Available at: http:// www.mednovosti.by/journal. aspx? article $=229$. 
Acknowledgment. The authors express their gratitude to H.L. Ivanova, translator at the Republican Research Center for Radiation Medicine and Human Ecology, for editorship and adoption of the article.

Благодарность. Авторы выражают благодарность Е.Л. Ивановой, переводчику Республиканского научно-практического центра радиационной медицины и экологии человека, за редактирование рукописи.

\section{Authors' contributions}

E.A. Povelitsa: direct and practical performance of reconstructive surgery, data collection and processing, analysis of the obtained data, preparation and approval of the text with the coauthors, editing the text according to the requirements of the publisher, completion of supporting documents;

A.V. Bystrenkov, A.M. Shesternya: direct and practical performance of surgical intervention;

O.V. Parkhomenko: direct and practical participation in the surgery, writing the article, editorial revision.

Вклад авторов

Э.А. Повелица: непосредственное выполнение реконструктивных операций, сбор и обработка данных, анализ полученных данных, подготовка текста и согласование его с соавторами, редактирование текста в соответствии с требованиями издателя, заполнение сопроводительных документов;

А.В. Быстренков, А.М. Шестерня: выполнение хирургического вмешательства;

О.В. Пархоменко: непосредственное участие в операции, написание статьи, редакционная доработка.

Conflict of interest. The authors declare no conflict of interest.

Конфликт интересов. Авторы заявляют об отсутствии конфликта интересов.

Financing. The study was performed without external funding.

Финансирование. Исследование проведено без спонсорской поддержки.

Informed consent. The patient gave written informed consent to participate in the study.

Информированное согласие. Пациент подписал информированное согласие на участие в исследовании.

Статья поступила: 30.08.2019. Принята к публикации: 01.10.2019.

Article received: 30.08 .2019 . Accepted for publication: 01.10.2019. 